\title{
Lisu Chinese
}

National Cancer Institute

\section{Source}

National Cancer Institute. Lisu Chinese. NCI Thesaurus. Code C158178.

A Chinese person from the Lisu ethnic group. 